\title{
Predictive value of preoperative neutrophil-to-lymphocyte ratio while detecting bowel resection in hernia with intestinal incarceration
}

\author{
Hande Köksal, M.D., ${ }^{1}$ Derviş Ateş, M.D., ${ }^{1}$ Emet Ebru Nazik, M.D., ${ }^{1}$ İknur Küçükosmanoğlu, M.D., ${ }^{2}$ \\ Serap Melek Doğan, M.D., ${ }^{1}$ Osman Doğru, M.D. ${ }^{1}$
}

${ }^{1}$ Department of General Surgery, Health Sciences University, Konya Training and Research Hospital, Konya-Turkey

${ }^{2}$ Department of Pathology, Health Sciences University, Konya Training and Research Hospital, Konya-Turkey

\begin{abstract}
BACKGROUND: The aim of this study was to evaluate the relationship between preoperative hematological inflammatory markers of the patients who underwent a surgery for incarcerated hernia and intestinal resection requirement.

METHODS: The data of 102 patients who underwent a surgery for incarcerated hernia were retrospectively evaluated. Whole blood cell counts were preoperatively measured, and operation types and pathology results were recorded. The patients with intestinal resections were compared with those without any resection in terms of leukocyte number, neutrophil rate, red cell distribution width (RDW), platelet distribution width, neutrophil-to lymphocyte ratio (NLR), platelet to lymphocyte ratio (PLR), and mean platelet volume (MPV).

RESULTS: Eighty-one patients were operated for incarcerated groin hernia, 17 for incarcerated umbilical hernia, and 4 for incarcerated incisional hernia. Twenty-six patients (25\%) had intestinal resections; in 4 of them, intestinal perforation was detected. In patients with intestinal resections, the neutrophil rate, PDW, NLR, and PLR values were significantly higher than those in the patients without any resections.
\end{abstract}

CONCLUSION: High NLR rates, certainly with clinical correlation, can be used as a biomarker to predict intestinal necrosis and the need for intestinal resection in patients who will undergo surgery for incarcerated hernia, particularlyin situations with lacking radiological imaging methods.

Keywords: Incarcerated hernia; neutrophil to lymphocyte ratio; resection.

\section{INTRODUCTION}

Abdominal wall hernias such as groin, femoral, or incisional are one of the common problems during surgeries, and the incarceration of the hernias is one of the emergent situations, which are generally urgently operated. When the bowel is strangulated, it can lead to life-threatening complications, including bowel necrosis, perforation, or peritonitis. An early prediction of these complications and surgery planning are crucial for surgeons. It is essential to develop new diagnostic methods or markers for the early detection of these compli- cations. The studies on similar complications in acute mesenteric ischemia have been reported so far. ${ }^{[1-4]}$

Leukocyte and platelet counts and neutrophil ratio are known and often used as hematological inflammatory markers. In particular, neutrophil-to-lymphocyte ratio (NLR) and platelet-to-lymphocyte ratio (PLR) have been recently used as hematological inflammatory markers. The increase in neutrophil count during inflammation is recognized, which leads to relative lymphopenia in these cases. Hence, NLR reflects the underlying inflammation. It has been used for the early

Cite this article as: Köksal H, Ateş D, Nazik EE, Küçükosmanoğlu İ, Doğan SM, Doğru O. Predictive value of preoperative neutrophil-to-lymphocyte ratio while detecting bowel resection in hernia with intestinal incarceration. Ulus Travma Acil Cerrahi Derg 2018;24:207-210.

Address for correspondence: Hande Köksal, M.D.

Sağlık Bilimleri Üniversitesi, Konya Eğitim ve Araştırma Hastanesi, Genel Cerrahi Kliniği, Konya, Turkey

Tel: +90 332 - 2210000 E-mail: drhandeniz@yahoo.com

Ulus Travma Acil Cerrahi Derg 2018;24(3):207-210 DOI: 10.5505/tjtes.2017.93937 Submitted: 26.12.2016 Accepted: 26.09.2017 Online: 09.05.2018

Copyright 2018 Turkish Association of Trauma and Emergency Surgery 
detection of different inflammatory processes such as acute appendicitis, pancreatitis, and mesenteric ischemia. ${ }^{[1,4-8]}$ The number of similar studies on complicated hernias, including strangulation and incarceration, is limited. ${ }^{9,10]}$

The aim of this study was to evaluate the predictive value of the preoperative hematological inflammatory markers, including NLR, PLR, red cell distribution width (RDW), platelet distribution width (PDW), and mean platelet volume (MPV), while detecting the need for bowel resection in hernia with intestinal incarceration.

\section{MATERIALS AND METHODS}

The patients who underwent surgery for incarcerated hernias in our clinic from January 2014 to December 2015 were retrospectively evaluated. Preoperatively obtained complete blood counts, operation types, and pathology results were recorded from their files. Leukocyte count, neutrophil rate, RDW, PDW, and MPV were obtained from the patients' complete blood counts. NLR and PLR were also calculated.

For statistical assessment, the Statistical Package for Social Sciences (version 16.0; Chicago, IL, USA) program was used. Median values were used to analyze demographic characteristics. Parametric data is provided as arithmetic mean \pm standard deviation. For comparing categorical variables, Pearson chi-square test was used, and the comparison between the groups was assessed by Student's t-test or Mann-Whitney $U$-test (parametric and non-parametric data, respectively). In the statistical evaluations, a $p$-value $<0.05$ was regarded as statistically significant.

\section{RESULTS}

We enrolled 102 patients who underwent surgery for incarcerated hernia in this study. The age of the patients ranged from 21 to 89 years with a median age 68 years; 60 of the patients were males (59\%) and 42 patients were females (4I\%). Eighty-one patients were operated for incarcerated groin hernia, 17 for incarcerated umbilical hernia, and 4 patients for incarcerated incisional hernia. Twenty-six patients (25\%) had intestinal resections; in 4 of them, intestinal perforation was detected. In the patients with intestinal resections, the neutrophil rate, PDW, NLR, and PLR values were significantly higher than in those without any resections (Table I).

The PDW values of the patients with and without bowel resection were $14.38 \pm 3.01$ and $12.69 \pm 2.25$, respectively, and the difference was significant statistically $(p=0.002)$. According to the pathologic examination, the neutrophil rate, PDW, NLR and PLR values of the patients with bowel necrosis were higher than those of the patients without bowel necrosis $(p=0.026, p=0.002, p=0.019$, and $p=0.032$, respectively).

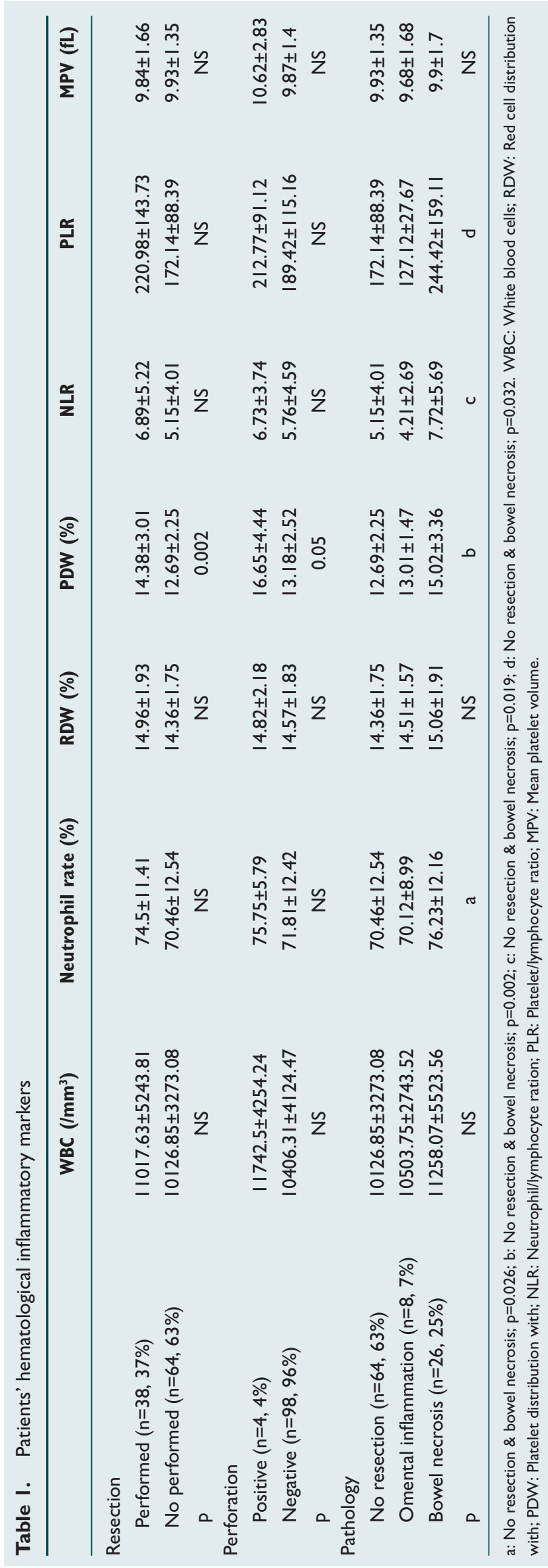




\section{DISCUSSION}

Abdominal wall hernias are one of the common problems during surgeries. Surgical approach is only a treatment choice. Sometimes, the contents of the hernia sac can be incarcerated in the abdominal wall. Incarcerated hernia can become strangulated, particularly when the bowel blood flow impairs, and it can cause bowel ischemia and necrosis. Incarceration, bowel ischemia, and necrosis can be life-threatening. In particular, the early detection of bowel ischemia and necrosis are crucial for planning the surgery. The studies on the early detection of ischemia and necrosis are mostly about acute mesenteric ischemia. ${ }^{[1-4]}$

In a study by Karabulut et al., ${ }^{[3]}$ the role of procalcitonin and phosphorus in the early diagnosis of acute mesenteric ischemia were evaluated. They found that the maximum elevation in the procalcitonin and phosphorus levels was detected at the third hour of ischemia. They concluded that procalcitonin and phosphorus can be used in the early diagnosis of acute mesenteric ischemia. In another study, a different biomarker such as C-reactive protein, leukocyte count, MPV, RDW, and NLR were used in the early detection of acute mesenteric ischemia. The NLR levels were high in patients with acute mesenteric ischemia. Optimal sensitivity (50\%) and specificity (66.1\%) for NLR was $7.85 \%$ in the ROC analysis. $^{[1]}$

The roles of NLR, leukocyte count, RDW, and MPV in the patients with acute mesenteric ischemia, acute appendicitis, and normal appendix were investigated. The RDW and NLR values were higher in the patients with acute mesenteric ischemia than those in patients with acute appendicitis. Moreover, leukocyte count, MPV, RDW, and NLR were higher in the patients with acute mesenteric ischemia than those in patients with normal appendix. They concluded that high NLR can be valuable for the early detection of acute mesenteric ischemia. $^{[4]}$

Recently, NLR calculated from complete blood count has been used in different inflammatory conditions. ${ }^{[1,4-10]}$ Different studies reported about patients diagnosed with acute appendicitis. $^{[5-7]}$ Preoperative NLR seems to be a valuable predictor of gangrenous appendicitis. In this study, they concluded that high NLR $(>8)$ levels can predict severe acute appendicitis. ${ }^{[5]}$ In another study by Cigsar et al., ${ }^{[6]}$ it was found that NLR could predict positive appendectomy in non-geriatric patients; however, it could not be valid in geriatric patients. In a detailed report by Sevinç, ${ }^{[7]}$ if a patient with a suspected diagnosis of acute appendicitis has high NLR $(>3)$, it was correlated with a definitive diagnosis. If a patient with acute appendicitis has NLR $>4.8$, the probability of perforation is high.

In incarcerated hernias, the role of the ischemia-modified albumin in the early detection of ischemia was investigated in an animal study by Kadioğlu et al. ${ }^{[10]}$ In this study, the ischemia-modified albumin levels in incarceration and strangulation groups were higher than those in sham group. Furthermore, the ischemia-modified albumin level of the strangulation group was higher than that of the incarceration group. They concluded that ischemia-modified albumin seems to be an effective predictive marker of early detection of necrosis in patients with incarcerated hernias. In the study about the patients with strangulated inguinal hernia by Zhou et al., ${ }^{\left[{ }^{[1]}\right.}$ they studied the clinical value of NLR. NLR of the patients with obvious bowel ischemia was higher than that of the patients without bowel ischemia. Another finding from the study was that NLR, hernia type, and the organ in the hernia sac were significantly related to strangulation according to the multivariate analysis.

In our study, the patients with intestinal resections were compared with those without any resection in terms of the leukocyte number, neutrophil rate, RDW, PDW, NLR, PLR, and MPV. In the patients with bowel resections, the neutrophil rate PDW, NLR, and PLR were significantly higher.

In conclusion, routinely used preoperative hematologic parameters can aid in the preoperative decision of bowel resection in patients with incarcerated hernia, particularlyin situations with lacking radiological imaging methods. However, prospective studies with large number of patients are needed in the further determination of the cut-off values of these parameters.

\section{Conflict of interest: None declared.}

\section{REFERENCES}

1. Tanrıkulu Y, Şen Tanrıkulu C, Sabuncuoğlu MZ, Temiz A, Köktürk F, Yalçın B. Diagnostic utility of the neutrophil-lymphocyte ratio in patients with acute mesenteric ischemia: A retrospective cohort study. Ulus Travma Acil Cerrahi Derg 2016;22:344-9.

2. Chau GY, Lui WY, King KL, Wu CW. Evaluation of effect of hemihepatic vascular occlusion and the Pringle maneuver during hepatic resection for patients with hepatocellular carcinoma and impaired liver function. World J Surg 2005;29:1374-83. [CrossRef]

3. Karabulut K, Gül M, Dündar ZD, Cander B, Kurban S, Toy H. Diagnostic and prognostic value of procalcitonin and phosphorus in acute mesenteric ischemia. Ulus Travma Acil Cerrahi Derg 2011;17:193-8.

4. Aktimur R, Cetinkunar S, Yildirim K, Aktimur SH, Ugurlucan M, Ozlem N. Neutrophil-to-lymphocyte ratio as a diagnostic biomarker for the diagnosis of acute mesenteric ischemia. Eur J Trauma Emerg Surg 2016;42:363-8. [CrossRef]

5. Ishizuka M, Shimizu T, Kubota K. Neutrophil-to-lymphocyte ratio has a close association with gangrenous appendicitis in patients undergoing appendectomy. Int Surg 2012;97:299-304. [CrossRef]

6. Cigsar G, Yildirim AC, Anuk T, Guzel H, Gunal E, Gulkan S, et al. Neutrophil to lymphocyte ratio on appendectomy of geriatric and nongeriatric patients. J Invest Surg 2017;30:285-90. [CrossRef]

7. Sevinç MM, Kınacı E, Çakar E, Bayrak S, Özakay A, Aren A, et al. Diagnostic value of basic laboratory parameters for simple and perforated 
acute appendicitis: an analysis of 3392 cases. Ulus Travma Acil Cerrahi Derg 2016;22:155-62.

8. Azab B, Jaglall N, Atallah JP, Lamet A, Raja-Surya V, Farah B, et al. Neutrophil-lymphocyte ratio as a predictor of adverse outcomes of acute pancreatitis. Pancreatology 2011;11:445-52. [CrossRef]

9. Hwang SY, Shin TG, Jo IJ, Jeon K, Suh GY, Lee TR, et al. Neutrophilto-lymphocyte ratio as a prognostic marker in critically-illseptic patients.
Am J Emerg Med 2017;35:234-9. [CrossRef]

10. Kadioğlu H, Ömür D, Bozkurt S, Ferlengez E, Memmı N, Ersoy YE, et al. Ischemia modified albumin can predict necrosis at incarcerated hernias. Dis Markers 2013;35:807-10. [CrossRef]

11. Zhou H, Ruan X, Shao X, Huang X, Fang G, Zheng X. Clinical value of the neutrophil/lymphocyte ratio in diagnosing adult strangulated inguinal hernia. Int J Surg 2016;36:76-80. [CrossRef]

\section{ORİIINAL ÇALIŞMA - ÖZET}

\section{Nötrofil-lenfosit oranı inkarsere hernisi olan hastalarda ameliyat öncesi dönemde bağırsak nekrozunu öngörmede bir belirteç olabilir mi?}

Dr. Hande Köksal, ${ }^{1}$ Dr. Derviş Ateş, ${ }^{1}$ Dr. Emet Ebru Nazik, ${ }^{1}$ Dr. İlknur Küçükosmanoğlu, ${ }^{2}$

\section{Dr. Serap Melek Doğan, ${ }^{1}$ Dr. Osman Doğru ${ }^{1}$}

${ }^{1}$ Sağlık Bilimleri Üniversitesi, Konya Eğitim ve Araştırma Hastanesi, Genel Cerrahi Bölümü, Konya

${ }^{2}$ Sağlık Bilimleri Üniversitesi, Konya Eğitim ve Araştırma Hastanesi, Patoloji Bölümü, Konya

AMAÇ: Çalışmanın amacı inkarsere herni nedeniyle acil ameliyat planlanan hastalarda ameliyat öncesi dönemdeki nötrofil/lenfosit oranı (NLR) ile olası bağırsak rezeksiyonu gerekliliği arasında ilişki olup olmadığının araştırılmasıdır.

GEREÇ VE YÖNTEM: İnkarsere herni nedeniyle ameliyat edilen 102 hastanın verileri geriye dönük olarak incelendi. Ameliyat öncesi tam kan sayımları ile yapılan ameliyat ve varsa patoloji sonuçları kaydedildi. Bağırsak rezeksiyonu yapılan hastalarla yapılmayan hastalar lökosit sayısı, nötrofil oranı, eritrosit dağılım genişliği (RDW), trombosit dağılım genişliği (PDW), NLR, trombosit/lenfosit oranı (PLR) ve ortalama trombosit hacmi (MPV) açısından karşılaştırıldı.

BULGULAR: Hastaların 8I'i inkarsere inguinal herni, I7'si inkarsere umblikal herni ve dördü de inkarsere insizyonel herni nedeniyle ameliyat edilmişti. Hastalardan 26'sına (\%25) ameliyat sırasında bağırsak rezeksiyonu yapılmış ve dördünde bağırsak perforasyonu saptanmıştı. Bağırsak rezeksiyonu yapılan grupta nötrofil oranı, PDW, NLR ve PLR değerleri bağırsak rezeksiyonu yapılmayan gruba göre anlamlı oranda yüksekti.

TARTIŞMA: Yüksek NLR değerleri klinikle birlikte değerlendirildiğinde; özellikle görüntüleme yöntemlerinin kullanılamadığı durumlarda inkarsere herni nedeniyle ameliyat edilecek hastalarda bağırsak nekrozu ve rezeksiyon gerekliliğini ameliyat öncesi dönemde öngörmede yardımcı bir belirteç olarak kullanılabilir.

Anahtar sözcükler: İnkarsere herni; nötrofil-lenfosit oranı; rezeksiyon.

Ulus Travma Acil Cerrahi Derg 2018;24(3):207-210 doi: 10.5505/tjtes.2017.93937 